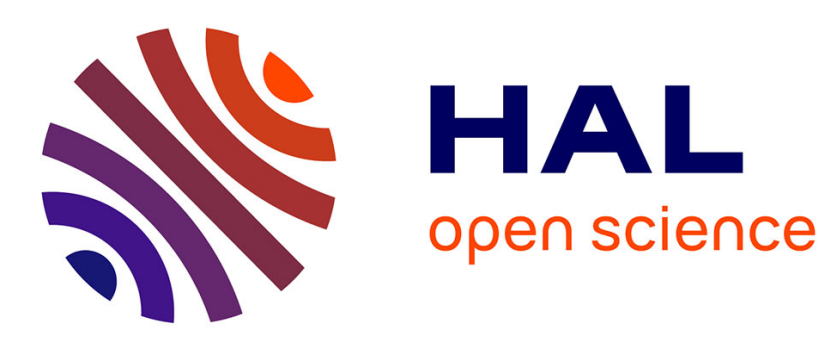

\title{
Trade-off between height growth and spring flushing in common beech (Fagus sylvatica L.) \\ Gömöry, Paule
}

\section{To cite this version:}

Gömöry, Paule. Trade-off between height growth and spring flushing in common beech (Fagus sylvatica L.). Annals of Forest Science, 2011, 68 (5), pp.975-984. 10.1007/s13595-011-0103-1 . hal-00930670

\section{HAL Id: hal-00930670 https://hal.science/hal-00930670}

Submitted on 1 Jan 2011

HAL is a multi-disciplinary open access archive for the deposit and dissemination of scientific research documents, whether they are published or not. The documents may come from teaching and research institutions in France or abroad, or from public or private research centers.
L'archive ouverte pluridisciplinaire HAL, est destinée au dépôt et à la diffusion de documents scientifiques de niveau recherche, publiés ou non, émanant des établissements d'enseignement et de recherche français ou étrangers, des laboratoires publics ou privés. 


\title{
Trade-off between height growth and spring flushing in common beech (Fagus sylvatica L.)
}

\author{
Dušan Gömöry • Ladislav Paule
}

Received: 15 July 2010 /Accepted: 30 January 2011 /Published online: 6 July 2011

(C) INRA and Springer Science+Business Media B.V. 2011

\begin{abstract}
- Introduction The annual development cycle of boreal and temperate trees results from an evolutionary trade-off between two opposing forces. These are namely, the adjustment of leaf phenology to the timing of frost occurrence at the beginning and/or the end of the growth season countered by an effective adjustment to the duration of the growth season to maximise photosynthesis and biomass production during the growing season.

- Objectives In a provenance trial of common beech (Fagus sylvatica L.) populations, we tested whether avoiding frost events by late flushing is the primary process of frost tolerance, and also, whether longer growth seasons resulted in an increase in biomass production.

- Results We detected clines with altitude and longitude of provenances for phenological traits, in contrast to growth variables. A highly significant negative genetic correlation was detected between frost damage and budburst date which confirms that the timing of leaf flushing is the principal determinant of tolerance to late frost.

Height and diameter growth were positively correlated with the length of the vegetation season. However, this effect was associated with the timing of growth cessation rather than with budburst.
\end{abstract}

\section{Handling Editor: Luc Pâques}

Electronic supplementary material The online version of this article (doi:10.1007/s13595-011-0103-1) contains supplementary material, which is available to authorized users.

D. Gömöry $(\bowtie) \cdot$ L. Paule

Faculty of Forestry, Technical University in Zvolen,

TG Masaryka 24,

96053 Zvolen, Slovakia

e-mail: gomory@vsld.tuzvo.sk
- Conclusions Stabilizing selection, selective pressure on early leaf flushing of juveniles in dense natural beech stands, and epigenetic regulation of budburst are proposed as explanations for these observations.

Keywords Common beech - Local adaptation . Evolutionary trade-off · Frost damage .

Vegetative phenology

\section{Introduction}

Vegetative phenology is considered to be one of the determinants of growth and biomass production in trees (Mimura and Aitken 2010). The timings of budburst and leaf senescence limit canopy duration and thus affect the carbon assimilation rates and the energy budget of forest ecosystems at all levels from a single stand to the global scale (Kindermann et al. 1996).

There is wide agreement that the timing of leaf flushing in the spring results from opposing evolutionary pressures in forest trees. An early budburst increases the length of the available growing season (capacity adaptation). On the other hand, later budburst decreases the risk of frost damage to actively growing parts (survival adaptation; Leinonen and Hänninen 2002; Loehle 1998; Vitasse et al. 2009). An optimised trade-off between prolonged vegetation and frost damage avoidance is expected to ensure maximal fitness of an individual under a given climate in the long-term, and may thus be considered an evolutionarily stable strategy sensu Maynard-Smith (1982).

There are controversial reports about the mechanisms controlling budburst in European beech. In temperate 
deciduous trees, the developmental processes associated with bud dormancy release are generally controlled by temperature in the form of a required chilling period followed by the accumulation of forcing temperatures (Kramer 1994). The role of photoperiod is unclear, particularly in beech. Heide (1993) or Lechowicz (1984) emphasized the importance of day length. In contrast, Kramer (1994) concluded that bud dormancy in beech is determined mainly by winter chilling. There might also be a geographic variation in the signals for breaking bud dormancy in beech; Falusi and Calamassi (1996) reported that a possible compensation between winter chilling and day length may depend on the latitude of origin.

Less is known about the climatic signals controlling the onset of dormancy in the autumn, showing overall less year-to-year variability. Both the photoperiod and the temperature regime seem to play a role in the timing of leaf senescence (Delpierre et al. 2009; Estrella and Menzel 2006).

In spite of the general consent about the evolutionary trade-off between growth and frost damage avoidance reflected in the optimization of the timing of growing season duration, this hypothesis apparently has not been tested explicitly. To address it, we studied relationships between vegetative phenology, height and diameter growth, and frost damage in a provenance experiment with European beech (Fagus sylvatica L.). It has been demonstrated that at least the timing of budburst is a highly heritable trait in beech (von Wuehlisch et al. 1995a). Clear geographic clines and a strong correlation of budburst date with the temperature regime at the site of origin (von Wuehlisch et al. 1995b) indicate an adaptive significance of this trait. Under the trade-off hypothesis, a positive genetic correlation is expected between growth and growing season length, whereas budburst date and frost damage are expected to be negatively correlated. The objective of this study is testing, whether these expectations conform with reality in common beech.

\section{Materials and methods}

\subsection{Experimental material}

The study is based on a provenance experiment with European beech established under the coordination of the Federal Forest Research Centre, Institute of Forest Genetics in Grosshansdorf, Germany, comprising 23 trials. The majority of trial plots were planted in 2000 with 2year-old seedlings. The Slovak trial, located at Tále near the town of Zvolen, central Slovakia $\left(48^{\circ} 38^{\prime} \mathrm{N}, 19^{\circ} 02^{\prime} \mathrm{E}\right.$, $810 \mathrm{~m}$ a.s.1.), comprises 32 provenances covering most of the distribution range of beech in Europe, with the exception of the south western Balkans, south Italy and Spain (Table 1). The test was established under a randomized complete block design with three blocks, each plot containing initially 50 plants planted at $2 \times 1-\mathrm{m}$ spacing.

Phenotypic traits were assessed in 2007 and 2008. Spring leaf flushing was scored at 3-5-day intervals between April 1 and June 1, 2007 (13 scoring dates) using a seven-point scale (Table 2). Autumn leaf colouring was scored at 6-10-day intervals between September 5 and November 1, 2007 (six scoring dates) using a six-point scale (Table 2). Scoring was repeated in 2008 between April 10 and May 27 (eight dates) and between August 29 and October 27 (ten dates) using the same methodology.

Both budburst and leaf senescence represent processes of irreversible transition between two steady states. Therefore, phenological scores were fitted (least squares) to the sigmoid function to estimate the midpoint and duration of these processes:

$p=\frac{1+2 \tanh \frac{t-m}{d}}{2}$

where $p$ is the phenological stage, $t$ is the scoring date (Julian day), $m$ is the midpoint (Julian day) and $d$ is the duration (days) of leaf flushing and/or leaf colouring.

In 2007, two late frost events occurred during the flushing season, leading to extensive damage of beech forests in central Slovakia (April 22/23, May 1/2). Frost damage was scored in the trial on May 3, 2007, using a five-point scale (Table 2).

Height, root-collar diameter (at the $20 \mathrm{~cm}$ height) and breast-height diameter (at the $1.3 \mathrm{~m}$ height) were measured in 2008 before the beginning of shoot growth.

\subsection{Data analysis}

Phenotypic data were analysed under the mixed linear model using the procedure MIXED of SAS (2009). Blocks were considered a fixed-effect factor and provenances a random-effect factor. The best linear unbiased predictors (BLUP) of provenance means and variance components associated with random effects were also estimated by the procedure MIXED (Table 1).

To assess spatial independence of data, simple Mantel tests (correlations between the matrix of geographic distances and the matrix of differences in provenance means of phenotypic traits) were calculated and their significances were tested using 100,000 random permutations.

Existence of clinal variation was tested using linear regression of phenotypic data against geographical coordinates. Significances of regression coefficients were tested by the $t$ test against $H_{0}: b=0$. 


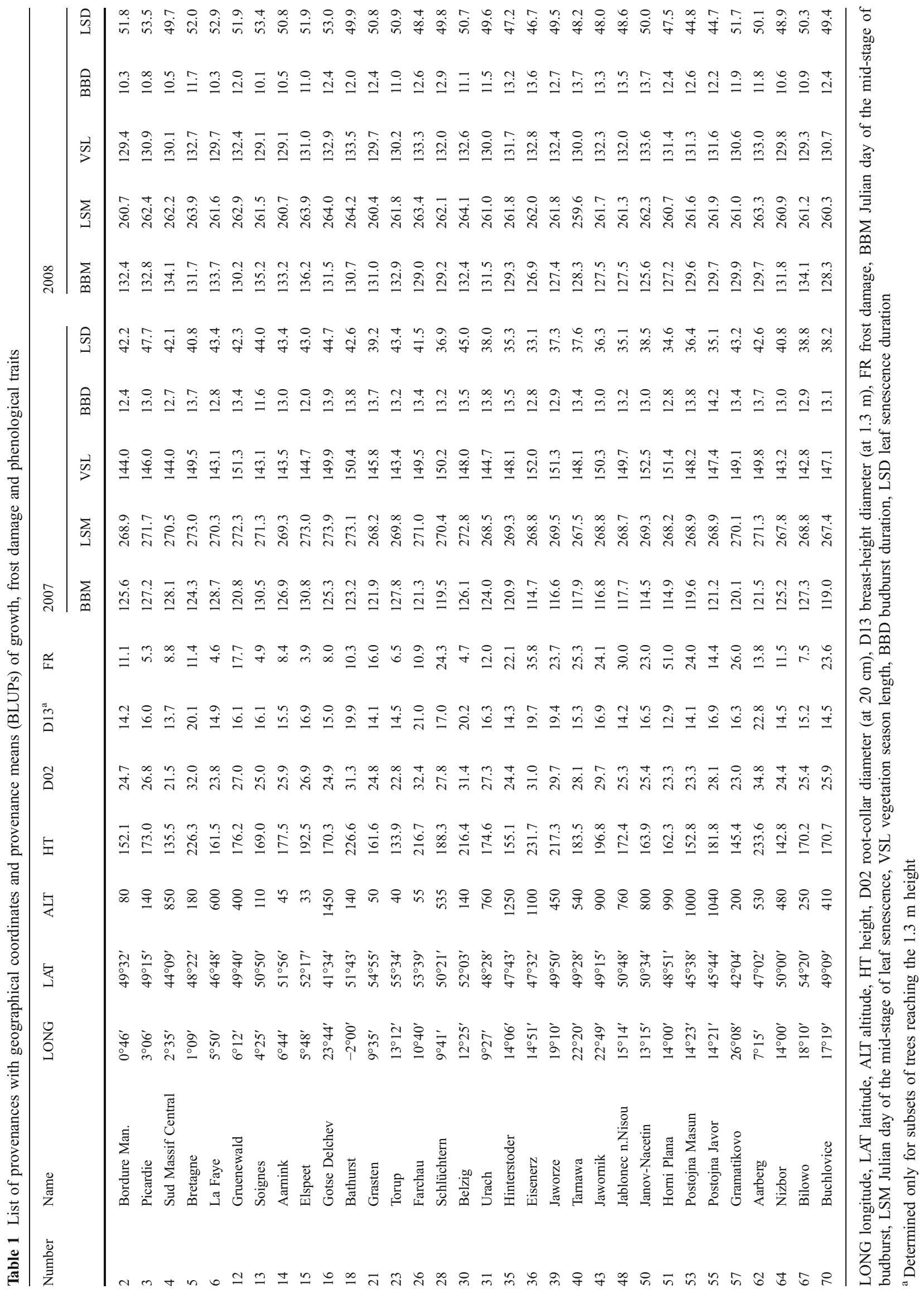


Table 2 Scoring scales for phenological stages and frost damage

\begin{tabular}{|c|c|}
\hline Score & Stage \\
\hline & Budburst phenology \\
\hline 1 & Dormant buds \\
\hline 2 & Buds swollen and elongated \\
\hline 3 & Buds begin to burst, first green is visible \\
\hline 4 & Folded and hairy leaves begin to appear \\
\hline 5 & Individually visible folded and hairy leaves \\
\hline 6 & Leaves unfolded, still fan-shaped, pale scales present \\
\hline \multirow[t]{2}{*}{7} & Leaves unfolded, smooth and bright \\
\hline & Autumn colouring \\
\hline 1 & Green leaves \\
\hline 2 & Beginning of autumn coloured of individual leaves \\
\hline 3 & $\begin{array}{l}\text { Beginning of autumn leaves colouring on a mass scale } \\
(5-10 \% \text { of leaves coloured) }\end{array}$ \\
\hline 4 & $\begin{array}{l}\text { Mass autumn leaves colouring } \\
\text { (about } 50 \% \text { of leaves coloured) }\end{array}$ \\
\hline 5 & Completed leaves colouring \\
\hline \multirow[t]{2}{*}{6} & Leaves started to be brown and dried. \\
\hline & Frost damage \\
\hline 0 & No damaged leaves (less than $5 \%$ ) \\
\hline 1 & $<1 / 3$ of leaves damaged \\
\hline 2 & $<2 / 3$ of leaves damaged \\
\hline 3 & $<95 \%$ leaves damaged \\
\hline 4 & All leaves $(>95 \%)$ damaged \\
\hline
\end{tabular}

Genotypic and phenotypic correlations between phenotypic traits were estimated using the method of moments based on a multivariate extension of the ordinary least squares (multivariate analysis of variance, cf. Mode and Robinson 1959). The GLM procedure (SAS 2009) using the MANOVA option was employed for the analysis. Provenance components of variances and covariances were used to calculate genetic correlations, whereas the sums of all random components were employed for phenotypic correlations.

\section{Results}

Differences among provenances were significant for almost all traits except vegetation-season length in 2008 (Table 3). There were also differences among blocks in phenology and frost damage, and provenances reacted differently to this micro-environmental heterogeneity, as indicated by significant provenance-by-block interactions. This methodological failure is associated with the layout of the trial plot. It was established within a limited area of a former forest nursery and was surrounded by an adult beech stand, where any spatial arrangement of blocks would produce differences in the behaviour of the planted material due to

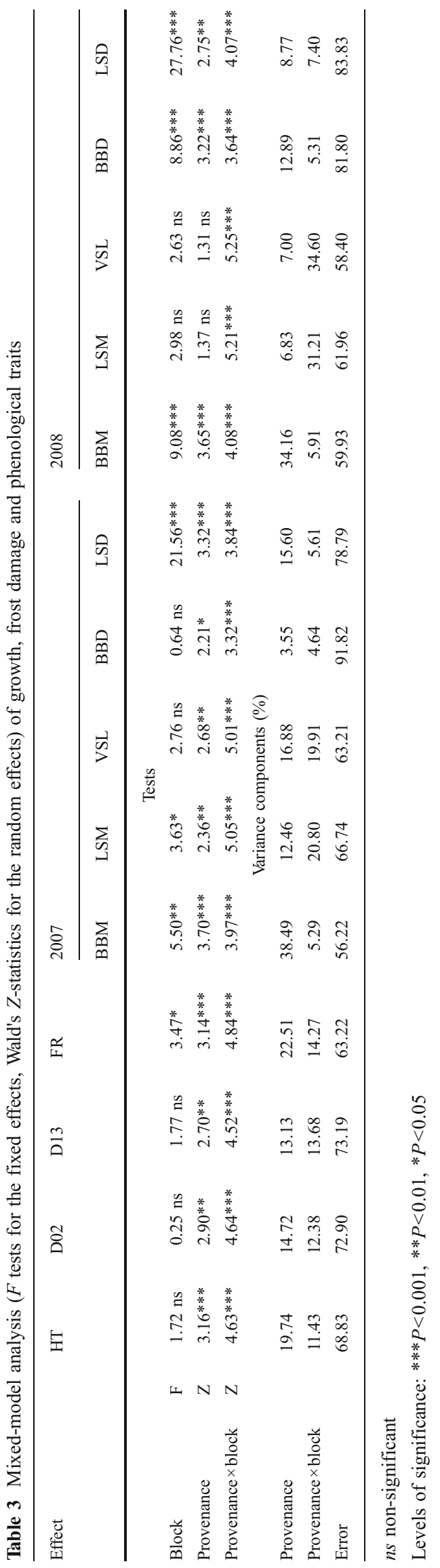


Table 4 Simple Mantel tests of spatial autocorrelation of growth, frost damage and phenological traits

\begin{tabular}{|c|c|c|c|c|c|}
\hline \multirow{5}{*}{$\begin{array}{l}\text { Table } 4 \text { Simple Mantel tests of } \\
\text { spatial autocorrelation of } \\
\text { growth, frost damage and } \\
\text { phenological traits }\end{array}$} & \multicolumn{2}{|c|}{$\begin{array}{ll}\mathrm{HT} & \mathrm{D} 02\end{array}$} & D13 & FR & \\
\hline & $0.072 \mathrm{~ns}$ & $0.017 \mathrm{~ns}$ & $\begin{array}{c}0.032 \text { ns } \\
2007\end{array}$ & $0.134^{*}$ & \\
\hline & BBM & LSM & VP & BBD & LSD \\
\hline & $0.163^{* *}$ & $0.223 * * *$ & $\begin{array}{c}-0.034 \mathrm{~ns} \\
2008\end{array}$ & $-0.085 \mathrm{~ns}$ & $0.131^{*}$ \\
\hline & $\mathrm{BBM}$ & LSM & VP & $\mathrm{BBD}$ & LSD \\
\hline $\begin{array}{l}\text { Levels of significance: as in } \\
\text { Table } 3\end{array}$ & $0.175^{* *}$ & $0.137 *$ & $-0.003 \mathrm{~ns}$ & $-0.052 \mathrm{~ns}$ & $0.165^{* *}$ \\
\hline
\end{tabular}

Levels of significance: as in Table 3

differences in lateral shading. Nevertheless, similar situations are quite common in breeding and transplant experiments with forest trees, and we consider the existence of unambiguous trends in phenology and frost damage to be proof of the validity of our observations.

Percentage of variance attributable to the effect of provenance varies; it is particularly high in the case of budburst date (34-38\%), but also reaches almost $20 \%$ for height growth (Table 3). Despite this, the residual withinprovenance variation, partly caused by genetic variation among trees within populations, represents by far the largest component in all traits, always exceeding $55 \%$.

Growth traits (height, diameters) did not exhibit any geographical patterns: they were neither spatially autocorrelated (Table 4), nor did they show any range-wide clinal trend (Fig. 1, Table 5). However, the results confirmed the existence of clear geographic clines in the timing of both spring flushing and autumn leaf colouring. Provenances from the eastern part of the range and from lower elevations tend to flush earlier in spring and terminate photosynthesis earlier in autumn (Fig. 1, Table 5). On the other hand, no latitudinal cline was found (see a complete overview of phenology - geography relationships provided in the Eletronic Supplementary Material). There was no clear pattern in the growing season length (Fig. 1).

Budburst date is very stable across years; genetic as well as phenotypic correlations between 2007 and 2008 are positive and highly significant for midpoint, but much less for the duration of leaf flushing. Leaf senescence midpoint is less correlated between years, which may indicate a more complicated regulation of this process. On the other hand, the duration of leaf colouring is more stable, compared to
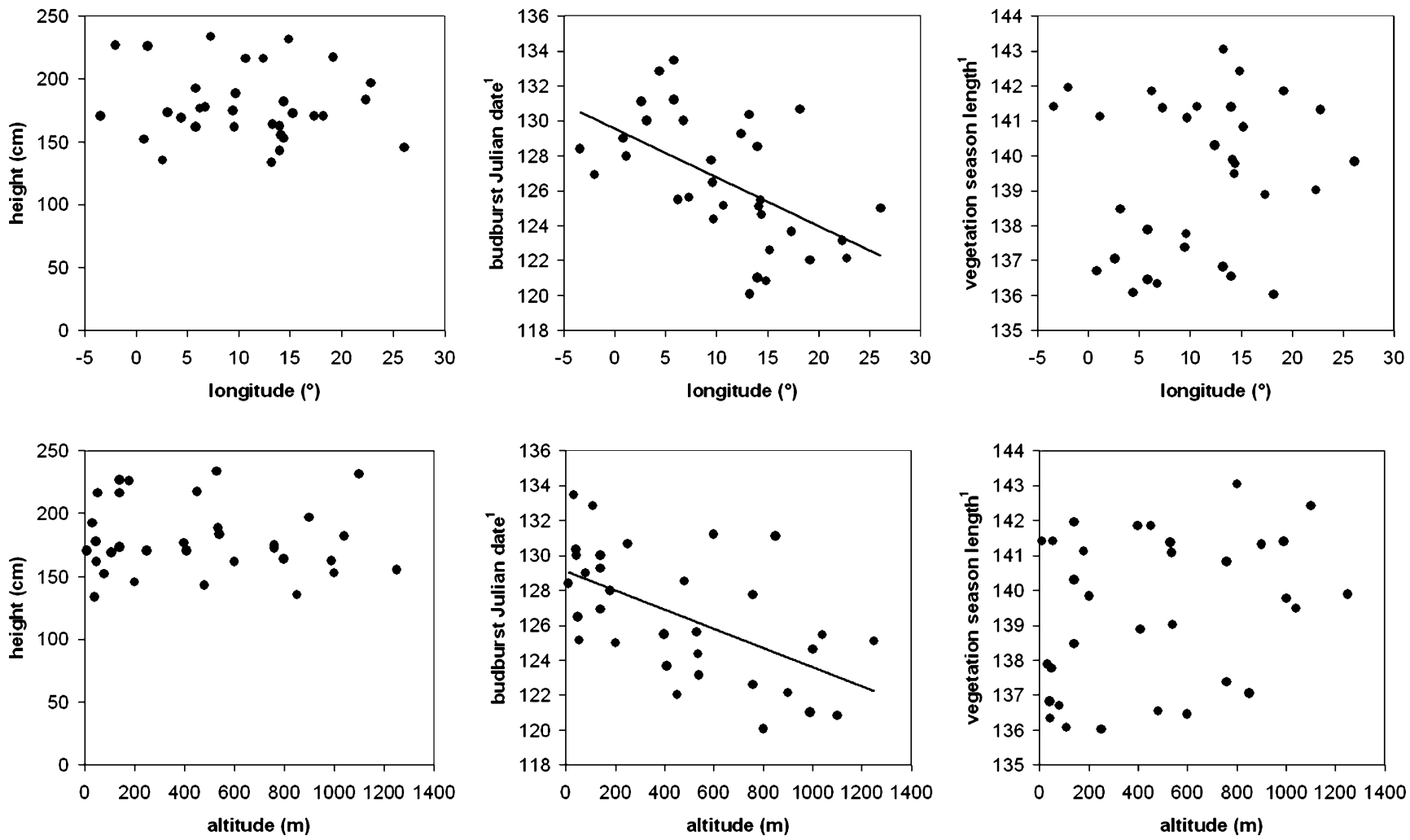

Fig. 1 Relationships between selected phenotypic traits and geographical coordinates. Superscripted number one:average over 2007 and 2008 
Table 5 Linear regressions ( $R^{2}$ and regression coefficients) of growth, frost damage and phenological traits against geographical coordinates
Levels of significance: as in Table 3

\begin{tabular}{|c|c|c|c|c|c|c|c|}
\hline \multirow[t]{2}{*}{ Year } & \multirow[t]{2}{*}{ Trait } & \multicolumn{2}{|l|}{ LONG } & \multicolumn{2}{|l|}{ LAT } & \multicolumn{2}{|l|}{ ALT } \\
\hline & & $R^{2}$ & $b$ & $R^{2}$ & $b$ & $R^{2}$ & $b$ \\
\hline & HT & 0.010 & $-0.388 \mathrm{~ns}$ & 0.008 & $0.765 \mathrm{~ns}$ & 0.006 & $-0.0060 \mathrm{~ns}$ \\
\hline & D02 & 0.004 & $-0.029 \mathrm{~ns}$ & 0.006 & $0.076 \mathrm{~ns}$ & 0.009 & $-0.0008 \mathrm{~ns}$ \\
\hline & D13 & 0.009 & $-0.032 \mathrm{~ns}$ & 0.000 & $-0.007 \mathrm{~ns}$ & 0.029 & $-0.0011 \mathrm{~ns}$ \\
\hline & FR & 0.299 & $0.807 * *$ & 0.106 & $-1.052 \mathrm{~ns}$ & 0.382 & $0.0174 * * *$ \\
\hline \multirow[t]{5}{*}{2007} & $\mathrm{BBM}$ & 0.319 & $-0.366^{* * *}$ & 0.061 & $0.350 \mathrm{~ns}$ & 0.336 & $-0.0071^{* * *}$ \\
\hline & LSM & 0.433 & $-0.165^{* * *}$ & 0.052 & $0.126 \mathrm{~ns}$ & 0.236 & $-0.0023^{* *}$ \\
\hline & VSL & 0.037 & $0.083 \mathrm{~ns}$ & 0.013 & $-0.107 \mathrm{~ns}$ & 0.112 & $0.0027 \mathrm{~ns}$ \\
\hline & $\mathrm{BBD}$ & 0.002 & $0.004 \mathrm{~ns}$ & 0.001 & $-0.004 \mathrm{~ns}$ & 0.021 & $0.0002 \mathrm{~ns}$ \\
\hline & LSD & 0.307 & $-0.281 * *$ & 0.060 & $0.272 \mathrm{~ns}$ & 0.603 & $-0.0075^{* * *}$ \\
\hline \multirow[t]{5}{*}{2008} & $\mathrm{BBM}$ & 0.271 & $-0.189 * *$ & 0.040 & $0.158 \mathrm{~ns}$ & 0.310 & $-0.0039 * * *$ \\
\hline & LSM & 0.284 & $-0.090 * *$ & 0.044 & $0.078 \mathrm{~ns}$ & 0.064 & $-0.0008 \mathrm{~ns}$ \\
\hline & VSL & 0.004 & $-0.013 \mathrm{~ns}$ & 0.002 & $0.018 \mathrm{~ns}$ & 0.038 & $0.0007 \mathrm{~ns}$ \\
\hline & $\mathrm{BBD}$ & 0.224 & $0.073 * *$ & 0.001 & $-0.012 \mathrm{~ns}$ & 0.259 & $0.0015^{* *}$ \\
\hline & LSD & 0.273 & $-0.162 * *$ & 0.105 & $0.219 \mathrm{~ns}$ & 0.562 & $-0.0044 * * *$ \\
\hline
\end{tabular}

budburst. The vegetation period duration as the difference between leaf flushing and leaf discoloration dates shows an intermediate interannual stability (Table 6).

There is a very close relationship between budburst date and duration $\left(R^{2}=0.67\right)$; later-flushing provenances tend to flush rapidly. Interestingly, just the opposite was observed for leaf discolouration (Fig. 2).

Frost damage was closely correlated with the leafflushing date: both genetic and phenotypic correlations are negative and highly significant (Table 7; since none of the variables are spatially independent, significance tests must be considered approximate).

A temporal shift of budburst by 1 day decreases late frost damage by $2 \%$ (Fig. 3 ).

Genetic correlations between growth traits (height, diameter) and the vegetation period duration are positive, fairly high and highly significant in both years (Table 7; see also the Electronic supplementary material). This relationship is illustrated by the example of height growth: a prolongation of the growing season by 1 day improves height at the age of 10 years by $7.4 \mathrm{~cm}$ (Fig. 3). At the same time, the correlations of growth variables with growing season length are higher than those with spring flushing or autumn leaf colouring dates. The only exception is the

Table 6 Genetic and phenotypic correlations of phenological traits between years $(2007$ and 2008)

Levels of significance: as in Table 3

\begin{tabular}{lll}
\hline Trait & $r_{\mathrm{G}}$ & $r_{\mathrm{P}}$ \\
\hline BBM & $0.983^{* *}$ & $0.882^{* *}$ \\
LSM & $0.845^{* *}$ & $0.750^{* *}$ \\
VSL & $0.914 * *$ & $0.749 * *$ \\
BBD & $0.305^{*}$ & $0.189 * *$ \\
LSD & $0.885^{* *}$ & $0.354 * *$ \\
\hline
\end{tabular}

correlation with breast-height diameter, where correlations with the timing of leaf senescence were found to be the greatest. However, this trait was measured only on a subset of the highest individuals, exceeding the recording height of $1.3 \mathrm{~m}$.

\section{Discussion}

Strictly speaking, the definition of genetic correlation implies using clonal replicates of single genotypes. However, in evolutionary studies as well as in the practice of tree breeding, a wider genetic or taxonomic entity such as family, population or taxon is often widely suggested to constitute a genotype (Schlichting 1986; Chambel et al. 2005). We used the terms "genetic" and "phenotypic" correlations as a sort of simplification rather than the more cumbersome terms "provenance-level" and "individuallevel" correlations, respectively. In fact, tree-level correlations also include a genetic component, associated with the genetic variation among individuals within a population.

The phenotypic variation in trees cannot be separated from its geographical context. Beech phenology is known to vary along both longitudinal and altitudinal gradients (von Wuehlisch et al. 1995b), which was also confirmed by our observations. Climatic contrasts among beech populations are huge, as illustrated by Fig. 4. At an oceanic site (Aguilar, La Rioja, Spain), the accumulation of temperatures is much more rapid than that in the interior (Králová, near the trial site). An arbitrarily chosen temperature sum of $500^{\circ} \mathrm{C}$ was reached on March 5 in Aguilar, but this was not achieved until as late as April 27 in Králová, despite an almost similar altitude for both sites. Using constant sum of 
Fig. 2 Relationships between budburst date and duration (left), and leaf discolouring date duration (right). Superscripted number one: average over 2007 and 2008

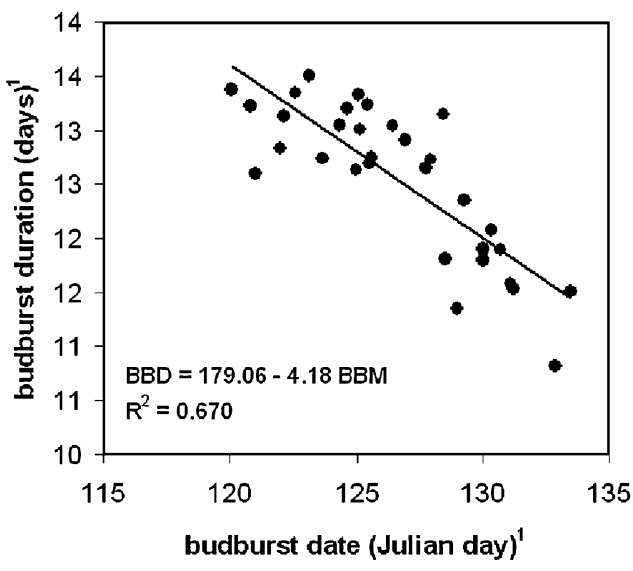

temperatures as a signal for vegetative processes would cause either an ineffective use of the vegetation season under the continental climate or a shift of flushing into wintertime under the oceanic climate. Populations of perennial plants have to develop mechanisms to cope with this climate variation.

As mentioned in the introduction, the adaptation of the timing of vegetative processes of trees to climate (at least in the boreal and temperate zones) has traditionally been considered to result from stabilizing selection driven by two opposing forces: the avoidance of frost damage during the cold season of the year, as opposed to maximum use of favourable growing conditions for photosynthesis and growth (Leinonen and Hänninen 2002). Such selection mechanisms require that avoiding frost events by late flushing is the primary mechanism of freezing tolerance, and that longer time available for growth is reflected in a higher biomass production.
Plants are known to protect themselves against cold by the accumulation of various compounds in the cytoplast and cell structures, such as oligosaccharides (Stushnoff et al. 1997), free proline (Reyes-Diaz et al. 2005), dehydrins (Kosová et al. 2007), heat-shock proteins (Lopez-Matas et al. 2004), or by changes in lipid composition and the degree of fatty acid saturation of the cell membranes (Čiamporová and Trgiňová 1999). These substances are believed to be involved in the freezing point depression of cell sap, the prevention of plasmolysis during cell dehydration caused by freezing, and also in membrane stabilization (ReyesDiaz et al. 2005). However, cold acclimation requires a certain time, as the maximum freezing tolerance of plants is not a constitutive trait, but is induced in response to low but non-freezing temperatures (below $10^{\circ} \mathrm{C}$; Alberdi and Corcuera 1991). Therefore, such defence mechanisms apply to mature vegetative tissues (such as evergreen leaves or needles) rather than to flushing leaves in the spring. In our

Table 7 Genetic and phenotypic correlations between growth/frost damage and phenological traits

\begin{tabular}{|c|c|c|c|c|c|c|c|c|}
\hline \multirow[t]{2}{*}{ Trait } & \multicolumn{2}{|l|}{ HT } & \multicolumn{2}{|l|}{ D02 } & \multicolumn{2}{|l|}{ D13 } & \multicolumn{2}{|l|}{ FR } \\
\hline & $r_{\mathrm{G}}$ & $r_{\mathrm{P}}$ & $r_{\mathrm{G}}$ & $r_{\mathrm{P}}$ & $r_{\mathrm{G}}$ & $r_{\mathrm{P}}$ & $r_{\mathrm{G}}$ & $r_{\mathrm{P}}$ \\
\hline \multicolumn{9}{|c|}{2007} \\
\hline BBM & $-0.202 \mathrm{~ns}$ & $-0.336^{* * *}$ & $-0.153 \mathrm{~ns}$ & $-0.237 * * *$ & $0.081 \mathrm{~ns}$ & $-0.083 \mathrm{~ns}$ & $-0.878 * * *$ & $-0.665 * * *$ \\
\hline LSM & $0.432 *$ & $0.236 * * *$ & $0.388^{*}$ & $0.297 * * *$ & $0.497 * *$ & $0.315 * * *$ & NA & NA \\
\hline VSL & $0.515^{* *}$ & $0.457 * * *$ & $0.430^{*}$ & $0.417 * * *$ & $0.295^{*}$ & $0.328 * * *$ & NA & NA \\
\hline BBD & $0.214 \mathrm{~ns}$ & $0.075^{* *}$ & $0.345^{*}$ & $0.111 * * *$ & $0.168 \mathrm{~ns}$ & $0.006 \mathrm{~ns}$ & $-0.050 \mathrm{~ns}$ & $-0.079 * *$ \\
\hline LSD & $-0.017 \mathrm{~ns}$ & $0.060 * *$ & $0.055 \mathrm{~ns}$ & $0.140 * * *$ & $0.208 \mathrm{~ns}$ & $0.162 * * *$ & NA & NA \\
\hline \multicolumn{9}{|c|}{2008} \\
\hline BBM & $-0.225 \mathrm{~ns}$ & $-0.391 * * *$ & $-0.203 \mathrm{~ns}$ & $-0.326 * * *$ & $0.027 \mathrm{~ns}$ & $-0.197 * * *$ & NA & NA \\
\hline LSM & $0.599 * * *$ & $0.253 * * *$ & $0.571 * * *$ & $0.313 * * *$ & $0.642 * * *$ & $0.312 * * *$ & NA & NA \\
\hline VSL & $0.654 * * *$ & $0.423 * * *$ & $0.614 * * *$ & $0.440 * * *$ & $0.550 * * *$ & $0.382 * * *$ & NA & NA \\
\hline BBD & $0.296^{*}$ & $0.263 * * *$ & $0.240 \mathrm{~ns}$ & $0.243 * * *$ & $-0.086 \mathrm{~ns}$ & $0.079 * *$ & NA & NA \\
\hline LSD & $-0.077 \mathrm{~ns}$ & $0.030 \mathrm{~ns}$ & $-0.084 \mathrm{~ns}$ & $0.021 \mathrm{~ns}$ & $-0.044 \mathrm{~ns}$ & $0.010 \mathrm{~ns}$ & NA & NA \\
\hline
\end{tabular}

Levels of significance: as in Table 3 
Fig. 3 Relationships between vegetation season length and height growth (left), and budburst date and late frost damage (right). Superscripted number one: average over 2007 and 2008

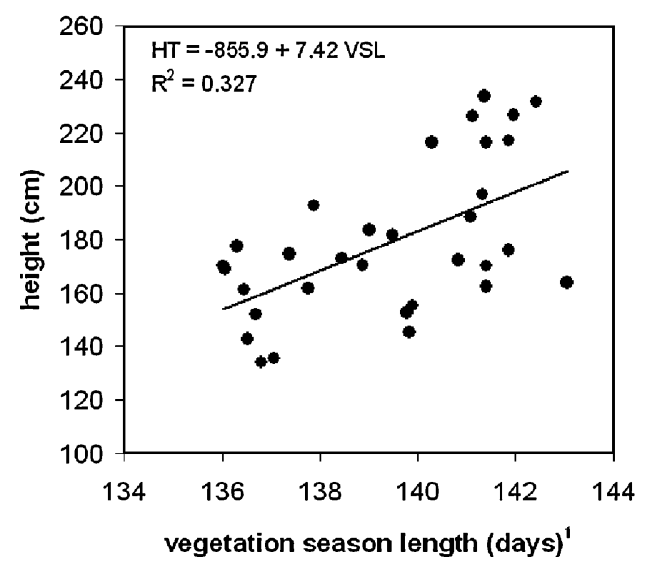

case, there was a very close negative provenance-level correlation between frost damage and the leaf-flushing stage, implying that the primary risk-avoidance strategy of beech with respect to late frosts is to delay bud break. Naturally, trees are capable of re-flushing following frost defoliation. In fact, beech woods in central Slovakia (including the damaged part of the provenance plot) recovered from the damage in May 2007. However, the second flush leaves differ in morphology and have lower nutrient and sucrose concentrations, which indicates a depletion of nutrient and carbohydrate leaf resources and may place constraints on growth capacity (St. Clair et al. 2009). Moreover, flowering in beech occurs simultaneously with leaf flushing. Systematically repeated destruction of the flowers by late frosts may hinder the natural regeneration of beech forests and thus endanger the persistence of beech populations over several generations.

Prolongation of the growing season was reflected in a higher growth rate. However, this effect seems to be associated primarily with delayed cessation rather than with an early beginning of vegetation. Genetic correlations of height or diameter with budburst date are consistently negative but non-significant. This is in agreement with the observations in other tree species, where such correlations are generally weak (El-Kassaby and Park 1993; Rehfeldt 1992), and in some cases even positive, meaning that trees may benefit from delayed bud break (Hawkins and Stoehr 2009; Li and Adams 1993). On the other hand, growing season length or vegetation cessation date are generally more closely correlated with height, diameter, dry weight or other indicators of biomass production (Dewald et al. 1992; Hawkins and Stoehr 2009; Rehfeldt 1992).

In temperate deciduous forests, early flushing of seedlings and saplings prior to the canopy closure is critical for their survival and growth (Augspurger 2008), thus an advance in bud break decreases with increasing height and age (Seiwa 1999). The advantage of early-flushing juveniles in dense beech woods may therefore be another mechanism maintaining the average timing of budburst at earlier dates.

The existence of clear clines has traditionally been interpreted as an outcome of adaptation by natural selection. There is, however, growing evidence of epigenetic memory mechanisms regulating the phenological behaviour of tree populations (Johnsen et al. 2005; Rohde and Junttila 2008). Most of this evidence is associated with
Fig. 4 Course of average daily temperatures and cumulative degree days during the winter/ spring 2007 at two contrasting sites. Sources of data: Technical University in Zvolen and Dirección General de Justicia e Interior de La Rioja (http://ias1. larioja.org/estaciones/estaciones/ mapa/portada/index.jsp)
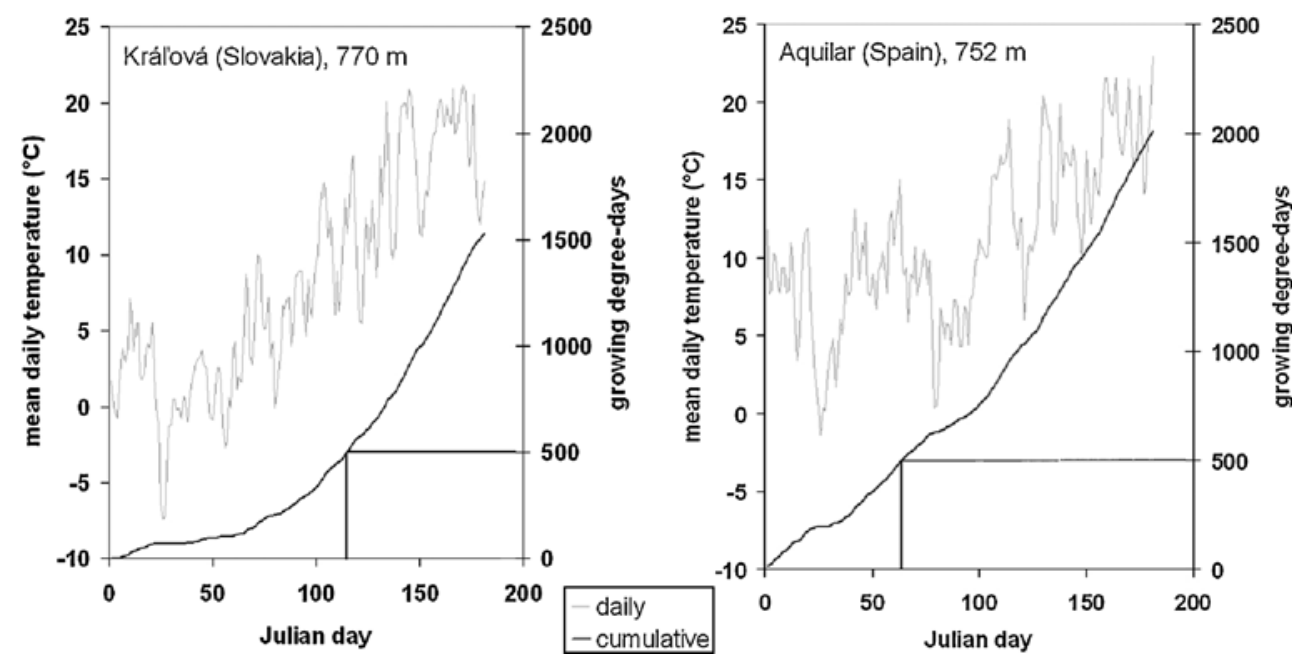
conifers (namely Norway spruce), having an incomparably larger genome and differing in epigenetic markings associated with heterochromatin (Fuchs et al. 2008). Moreover, beech as a long-lived species and difficult to be artificially crossed or propagated by somatic embryogenesis is among the least appropriate objects for the study of memory effects in angiosperms. Nevertheless, phenological behaviour of beech is quite fine-tuned to the temperature regime of the sites of origin (von Wuehlisch et al. 1995b), and it is questionable as to whether this can be explained by natural selection alone.

The absence of latitudinal trends and the presence of clear longitudinal and elevational clines support the hypothesis of climatic (temperature) rather than photoperiodic signals for the course of phenological processes. However, the genetic backgrounds of spring and autumn vegetative phenology must differ. The beginning of budburst is obviously heritable, but its course is driven by actual temperatures: provenances starting early accomplish budburst under generally colder weather and thus need a longer time to finish flushing. However, the relationship between mid-date and duration is just the opposite in autumn discoloration: western, late provenances require more time compared to local provenances to finish leaf colouring, in spite of decreasing temperatures during the late autumn and the risk of early frost damage. Autumn phenology is thus less affected by the environment of the plantation site; the behaviour of provenances apparently results from accommodation to the climate of the site of origin.

In conclusion, the data on common beech confirmed that an evolutionary trade-off between growth and frost avoidance exists to a certain extent, and is associated mainly with the autumn vegetative phenology. However, the underlying genetic (and potentially epigenetic) mechanisms are largely unknown and deserve further study.

Acknowledgements The provenance trial has been established through the realisation of the project European Network for the Evaluation of the Genetic Resources of Beech for Appropriate Use in Sustainable Forestry Management (Contract AIR3-CT94-2091) under the coordination of H.-J. Muhs and G. von Wuehlisch. Collection of field data was accomplished within the COST Action E52 Evaluation of Beech Genetic Resources for Sustainable Forestry. The study was supported by a grant of the Slovak Agency for Research and Development no. APVV-0441-07. The assistance of D. Krajmerová, I. Romšaková, G. Baloghová and H. Parobková with height and diameter measurements is highly appreciated. Weather data for the station Králová were kindly provided by K. Střelcová. We also wish to thank to D. Pauleová, E. Ritch-Krc and P. Svihra for language correction.

\section{References}

Alberdi M, Corcuera LJ (1991) Cold acclimation in plants. Phytochemistry 30:3177-3184
Augspurger CK (2008) Early spring leaf out enhances growth and survival of saplings in a temperate deciduous forest. Oecologia 156:281-286

Chambel MR, Climent J, Alía R, Valladares F (2005) Phenotypic plasticity: a useful framework for understanding adaptation in forest species. Invest Agrar Sist Recur For 14:334-344

Čiamporová M, Trgiňová I (1999) Modifications of plant cell ultrastructure accompanying metabolic responses to low temperatures. Biologia 54:349-360

Delpierre N, Dufrêne E, Soudani K, Ulrich E, Cecchini S, Boé J, François C (2009) Modelling interannual and spatial variability of leaf senescence for three deciduous tree species in France. Agr Forest Meteorol 149:938-948

Dewald L, White TL, Duryea ML (1992) Growth and phenology of seedlings of 4 contrasting slash pine families in 10 nitrogen regimes. Tree Physiol 11:255-269

El-Kassaby YA, Park YS (1993) Genetic variation and correlation in growth, biomass, and phenology of Douglas-fir diallel progeny at different spacings. Silvae Genet 42:289-297

Estrella N, Menzel A (2006) Responses of leaf colouring in four deciduous tree species to climate and weather in Germany. Clim Res 32:253-267

Falusi M, Calamassi R (1996) Geographic variation and bud dormancy in beech seedlings (Fagus sylvatica L.). Ann Sci For 53:967-979

Fuchs J, Jovtchev G, Schubert I (2008) The chromosomal distribution of histone methylation marks in gymnosperms differs from that of angiosperms. Chromosome Res 16:891-898

Hawkins BJ, Stoehr M (2009) Growth, phenology, and cold hardiness of 32 Douglas-fir full-sib families. Can J For Res 39:1821-1834

Heide OM (1993) Dormancy release in beech buds (Fagus sylvatica) requires both chilling and long days. Physiol Plantarum 89:187191

Johnsen Ø, Fossdal CG, Nagy N, Molmann J, Daehlen OG, Skrøppa $\mathrm{T}$ (2005) Climatic adaptation in Picea abies progenies is affected by the temperature during zygotic embryogenesis and seed maturation. Plant Cell Environ 28:1090-1102

Kindermann J, Wurth G, Kohlmaier GH, Badeck FW (1996) Interannual variation of carbon exchange fluxes in terrestrial ecosystems. Global Biogeochem Cy 10:737-755

Kosová K, Vítámvás P, Prášil IT (2007) The role of dehydrins in plant response to cold. Biol Plant 51:601-617

Kramer K (1994) Selecting a model to predict the onset of growth of Fagus sylvatica. J Appl Ecol 31:172-181

Lechowicz M (1984) Why do temperate deciduous trees leaf out at different times? Adaptation and ecology of forest communities. Am Nat 124:821-842

Leinonen I, Hänninen H (2002) Adaptation of the timing of bud burst of Norway spruce to temperate and boreal climates. Silva Fenn 36:695-701

Li P, Adams WT (1993) Genetic control of bud phenology in pole-size trees and seedlings of coastal Douglas-fir. Can J For Res 23:1043-1051

Loehle C (1998) Height growth rate tradeoffs determine northern and southern range limits for trees. J Biogeogr 25:735-742

Lopez-Matas MA, Nuñez P, Soto A, Allona I, Casado R, Collada C, Guevara MA, Argoncillo C, Gomez L (2004) Protein cryoprotective activity of a cytosolic small heat shock protein that accumulates constitutively in chestnut stems and is upregulated by low and high temperatures. Plant Physiol 134:17081717

Maynard Smith J (1982) Evolution and the theory of games. Cambridge University Press, Cambridge, 224 pages

Mimura M, Aitken SN (2010) Local adaptation at the range peripheries of Sitka spruce. J Evol Biol 23:249-258 
Mode CJ, Robinson HF (1959) Pleiotropism and the genetic variance and covariance. Biometrics 15:518-537

Rehfeldt GE (1992) Early selection in Pinus ponderosa - compromises between growth potential and growth rhythm in developing breeding strategies. For Sci 38:661-677

Reyes-Diaz M, Alberdi M, Piper F, Bravo LA, Corcuera LJ (2005) Low temperature responses of Nothofagus dombeyi and Nothofagus nitida, two evergreen species from south central Chile. Tree Physiol 25:1389-1398

Rohde A, Junttila O (2008) Remembrances of an embryo: long-term effects on phenology traits in spruce. New Phytol 177:2-5

SAS (2009) SAS/STAT ${ }^{\circledR}$ User's Guide, http://support.sas.com/documentation/onlinedoc/stat/index.html. Accessed 14 Feb 2010

Schlichting CD (1986) The evolution of phenotypic plasticity in plants. Ann Rev Ecol Syst 17:667-693

Seiwa K (1999) Changes in leaf phenology are dependent on tree height in Acer mono, a deciduous broad-leaved tree. Ann Bot 83:355-361

St. Clair SB, Monson SD, Smith EA, Cahill DG, Calder WJ (2009) Altered leaf morphology, leaf resource dilution and defense chemistry induction in frost-defoliated aspen (Populus tremuloides). Tree Physiol 29:1259-1268

Stushnoff C, Seufferheld MJ, Creegan T (1997) Oligosaccharides as endogenous cryoprotectants in woody plants. In: $\mathrm{Li} \mathrm{PH}$, Chen THH (eds) Plant Cold Hardiness - Molecular Biology, Biochemistry, and Physiology. Plenum Publishers, New York, pp 301-309

Vitasse Y, Porté AJ, Kremer A, Michalet R, Delzon S (2009) Responses of canopy duration to temperature changes in four temperate tree species: relative contributions of spring and autumn leaf phenology. Oecologia 161:187-198

von Wuehlisch G, Duval H, Jacques D, Muhs HJ (1995a) Stability of differences in flushing between provenances in different years and at different sites. In: Madsen SF (ed) Genetics and Silviculture of Beech. Danish Forest and Landscape Research Institute, Hørsholm, pp 83-89

von Wuehlisch G, Krusche D, Muhs HJ (1995b) Variation in temperature sum requirement for flushing of beech provenances. Silvae Genet 44:5-6 